\title{
Some Issues of Securing SDG 11 in the Legislation on Cultural and Ecological Tourism
}

\author{
Vitali Maksimeniuk $^{1}$, Roza Timakova ${ }^{2 *}$ \\ ${ }^{1}$ Belarusian State University, Minsk, Republic of Belarus \\ ${ }^{2}$ Ural State Universityof Economic, Yekaterinburg, Russian Federation \\ ${ }^{*}$ Correspondingauthor.Email:trt64@mail.ru
}

\begin{abstract}
This article discusses one of the aspects of sustainable development - the sustainable development of tourism in accordance with SDG 11, Task 11.4., aimed at intensifying efforts to protect and preserve the world cultural and natural heritage. The study of this phenomenon was carried out using the analysis of the most important regulatory legal acts operating in the field of tourism, nature protection and historical and cultural values in the Russian Federation and in the Republic of Belarus. Since the majority of authors attribute the purpose of travel to one of the generally accepted criteria for dividing into types of tourism, they consider quite common and popular types of tourism - cultural and environmental, the conceptual apparatus of which, at the same time, is formed under the influence of various conceptual approaches, based on the actual resource potential and features of the promotion of tourist services in the territories of tourist destinations. Based on the analysis of the legislation, conclusions are drawn about the degree of consolidation of Task 11.4. in the considered legislative acts, as well as proposals for amendments and additions to the existing regulatory legal acts are formed.
\end{abstract}

Keywords: sustainable development goals, sustainable tourism development, tourism legislation, cultural tourism, ecological tourism.

\section{INTRODUCTION}

In modern conditions of unstable development of socio-political relations, aggregation and interpenetration of national economies against the background of the ongoing pandemic of coronavirus infection in tourism, as one of the most affected industries, it is necessary to restart the industry. The formation of reference points for the transformation of the tourism industry on the basis of consolidation and partnership to achieve sustainable development takes place in accordance with the priority areas defined by the UN. The promising trends for improving the competitiveness of individual territories and the financial stability of the industry include universal digitalization (as well as for the entire economy) and greening.

The diversification of the tourism product as a result of the adaptation of the tourism infrastructure to the needs of domestic national and regional markets will ensure the recovery and consistent growth of sales.
The term "Sustainable Development Goals" (SDGs) has been firmly in use since 2015 in accordance with the UN General Assembly resolution "Agenda for the Period up to 2030", which defined 17 goals [1].

According to [2], sustainable development should be considered in different planes: as a principle leading to sustainable development; as an action program that provides a better state in accordance with a set of parameters, actions and tasks; as a function in accordance with the goals of sustainable development and the actual process with a change in quantitative indicators.

In the context of the development of the tourism industry, one of the fundamental goals can be considered the 11 SDGs "Ensuring openness, security, resilience and environmental sustainability of cities and settlements" in the context of task 11.4 - Protection of the world cultural and natural heritage.

At the same time, an important issue in a comparable assessment of the results of achieving this goal at the 
global level and at the level of individual states is the choice of an assessment indicator.

At the same time, an important issue in a comparable assessment of the results of achieving this goal at the global level and at the level of individual states is the choice of an assessment indicator.

In the Russian Federation, the indicator "Total expenditures per capita for the preservation, protection and preservation of all cultural and natural heritage" is used as an indicator, which is divided depending on the goal setting: by type of heritage (cultural, natural), sources of funding (public, private), level of management (national, regional, local / municipa).However, the application of such a calculation is associated with certain difficulties due to the vagueness of the concepts of cultural, natural and other types of activities for accounting purposes, which leads to double accounting at different management levels.

The concept of tourism development, which provides jobs for up to $10 \%$ of the working-age population of the globe, the effectiveness of which is largely determined by the complex impact of external factors: the safety and accessibility of ecosystems, the political and epidemiological situation (for example, COVID-19 pandemic), the development of infrastructure, etc., is formed in accordance with the relevant sustainable development goals [4].

The objectives of this study are to study and practically adapt the main provisions of task 11.4. SDG 11 to the modern legislation of the Russian Federation and the Republic of Belarus regulating public relations in the field of cultural and ecological tourism, to identify possible shortcomings of legal regulation, which will allow achieving the purpose of the study: making proposals to change the current legislation on tourism in terms of consolidating the principles and objectives of sustainable tourism development.

\section{MATERIALS AND METHODS}

The theoretical and methodological basis for the study of the current regulatory framework in the context of sustainable tourism development is the use of methods of system analysis and synthesis, structuralfunctional and empirical methods with the author's interpretation of the research results.

\section{RESULTS AND DISCUSSION}

According to [5], sustainable development, as a result of the implementation of integrated system approaches, is based on strategic planning methods without allocating separate tools.
For the sustainable development of tourism, the most important resource is the existing cultural and natural objects.

According to the first Voluntary National Review of the Russian Federation's achievement of the Sustainable Development Goals (SDGs) The United Nations and the implementation of the Sustainable Development Agenda for the period up to 2030 (the so-called Agenda 2030) have established that the preservation of biological and landscape diversity in specially protected natural areas (SPNA) attracts domestic and foreign tourists. There are about 12 thousand protected areas of federal, regional and local significance on the territory of the Russian Federation; at the same time, 24 federal and 17 regional protected areas are part of 12 World Heritage Sites[6].UNESCO World Heritage Sites contribute to the development of cultural tourism in Russia [7].

The Convention on the Protection of the World Cultural and Natural Heritage, adopted in 1972 at the UNESCO General Conference, is considered as a universal international act of a single document of the concept of nature protection and the preservation of cultural values [8]. Along with the UNESCO Convention, there is the Convention on the Protection of Cultural Property in the Event of Armed Conflict, adopted in 1954 [9].

A. T. Belekova [10] notes the increasing role and responsibility of UNESCO in the preservation and protection of cultural and historical heritage monuments as a result of deepening international cooperation and strengthening the mutual responsibility of the States parties to the UNESCO Convention for the Protection of the World Cultural and Natural Heritage, as well as resolute and uncompromising resistance to attempts by destructive forces to fragment and destroy the principles of spiritual space, as well as politicization of their activities.

At the beginning of 2021, the UNESCO World Heritage List includes 30 objects located on the territory of the Russian Federation (19 objects of cultural heritage and 11 objects of natural heritage), which is $2.6 \%$ of the total number (1,154 objects). There are 4 objects in the specified list in the Republic of Belarus, which is $0.3 \%$ of the total number: 3 objects of cultural heritage and 1 object of natural heritage.

Consistent planning of socio-economic policy, preservation and popularization of UNESCO World Heritage Sites among the world's population is possible as a result of a comprehensive analysis and evaluation of World Heritage sites by mapping all World Heritage sites [11].

The use of radar and optical satellite images from surveillance sensors will allow monitoring such objects to map sharp or slow changes in the landscape in order to improve their protection and management [12]. 
The correlating relationship of sustainable development with sustainable tourism determines the need for the formation of a competence-based approach to legislation in the field of tourism.

The purpose of the trip is the fundamental criterion for dividing into types of tourism and is considered at the public-legal level (customs declaration, border and migration control, etc.) and private-legal (civil contract for the provision of tourist services)[13].

Any type of tourism falls under the regulation of general regulatory legal acts on tourism and legislation regulating the procedure for providing tourist services that relate to a specific type of tourism.

The popular and widespread types of tourism both in the Russian Federation and in the Republic of Belarus include cultural and environmental. However, currently, the laws on tourism of the Russian Federation and the Republic of Belarus do not define cultural tourism. At the same time, the national laws on tourism of the Republic of Belarus, the Russian Federation, the Republic of Kazakhstan distinguish cognitive goals among the tourist goals. The Law of Ukraine "On Tourism" defines "cultural and educational tourism" as a separate type of tourism.

In the Global Code of Ethics for Tourism (1999), cultural goals are fixed among the main goals of tourist activity.

According to [14], cultural tourism has recently become a mass activity of people who carry it out, and has received significant development. One of the reasons for the rapid development of cultural tourism is the process of globalization, as a result of which the:

- economic;

- political;

- action interaction between states at the cultural level, as a result of which cultural tourism is becoming more widespread.

Researchers offer various definitions of cultural tourism. According to one of the opinions [15], cultural tourism is carried out in order to get acquainted with the objects of historical and cultural heritage.

Based on an objective analysis and the application of conceptual and effective approaches, an expanded definition of cultural tourism is proposed, when the tourist's desire to get acquainted with the historical and cultural heritage of the territories and visit various cultural events is the purpose of the trip.

In the Republic of Belarus, since 2016, the Code of Culture has been in force, which is aimed at regulating public relations in the field of culture, as well as establishing the legal, organizational, economic and social foundations of cultural activities in order to preserve and use cultural values, develop cultural organizations and ensure the general accessibility of cultural good. Article 3 of this Code lists the principles of regulation of social relations in the field of culture, which, in the context of the task under consideration, include the following principles:

- $\quad$ preservation and use of cultural values;

- $\quad$ saving and multiplying the historical, cultural and archaeological heritage.

Federal Law No. 73-FZ of 25.06.2002 "On Cultural Heritage Objects (Historical and Cultural Monuments) of the Peoples of the Russian Federation" regulates relations in the field of preservation, use, popularization and state protection of cultural heritage objects (historical and cultural monuments) of the peoples of the Russian Federation and is aimed at implementing the constitutional right of everyone to access cultural values and the constitutional duty of everyone to take care of the preservation of historical and cultural heritage. State protection of cultural heritage objects (historical and cultural monuments) is one of the priority tasks of the state authorities of the Russian Federation, state authorities of the constituent entities of the Russian Federation and local self-government bodies.

At the regional level, in particular, on the territory of the Sverdlovsk Region, the state program of the Sverdlovsk Region "State protection of cultural heritage objects located on the territory of the Sverdlovsk Region until 2024" (Decree of the Government of the Sverdlovsk Region No. 994-PP of 29.12.2016) has been approved and is in effect, the goals and objectives of which correspond to Strategies of the State Cultural policy of the Russian Federation No. 326-r of 29.02.2016 (Order of the Government of the Russian Federation) - preservation of cultural heritage and its popularization.

At the same time, the named Federal Law No. 73-FZ of 25.06.2002 does not contain an article on the principles of legal regulation. This situation, in our opinion, is problematic, since the consolidation of the goals and objectives for the preservation of cultural heritage in the Strategy of the State Cultural Policy of the Russian Federation, as well as in the normative legal acts of the subjects of the Russian Federation, does not fully embody the goals of sustainable development, in particular SDG 11. This is due to the temporary effect of regulatory legal acts (Strategy) or the restriction of their action to a certain territory (regulatory legal acts of the subjects of the Russian Federation).

Therefore, there is a need to consolidate the principles of sustainable development at the level of this Federal Law. 
The preservation of natural objects, including World Heritage Sites, should be considered in conjunction with the development of ecological tourism.

The Federal Law "On the Basics of Tourist activity in the Russian Federation" does not contain the concept of "ecological tourism". This type of tourism is mentioned in Article 3 of the Law of the Republic of Belarus "On Tourism", as well as in the national law on tourism of Uzbekistan

Article 4 of the Law of Turkmenistan "On Tourism" defines ecological tourism as "tourism carried out for the purpose of visiting unique natural objects, nature reserves, national natural parks, as well as participating in environmental protection activities"; in Article 1 of the Law of the Republic of Moldova "On the organization and implementation of tourism activities in the Republic of Moldova", - as "a type of tourism aimed at the knowledge of nature and its preservation".

The Strategy for the development of tourism in the Russian Federation for the period up to 2035, approved by the decree of the Government of the Russian Federation No. 2129-r of September 20, 2019, established that ecological tourism requires "...the formation of special measures of state support, the removal of administrative and socio-economic restrictions". According to State Standard GOST R 56642-2015 "Tourist services. Ecological tourism. General requirements "ecological tourism includes" travel organization activities that include all forms of natural tourism, in which the main motivation of tourists is observation and familiarization with nature in an effort to preserve it".In this sphere of public relations, there is a close relationship between the legislation on tourism and environmental legislation.

In the Republic of Belarus and in the Russian Federation, the same laws "On environmental Protection" are in force in the field of nature protection: Law of the Republic of Belarus No. 1982-XII of November 26, 1992 and Federal Law No. 7-FZ of 10.01.2002.

In these normative legal acts, the task 11.4. SDG 11 in terms of the protection of natural heritage has found its consolidation in articles that enshrine the principles of environmental protection. At the same time, the principles related to the issue under consideration in both Laws are largely identical.

In particular, it is:

- respect for the human right to a favorable environment;

- ensuring favorable conditions for human life;

- protection and rational (sustainable) use of natural resources;
- conservation of biological diversity, as well as some other principles.

According to the Passport of the national project " Ecology "(RF), approved in 2018 by the Presidium of the Presidential Council for Strategic Development and National Projects,"conservation of biological diversity and the development of ecological tourism" is fixed as the most important direction.

Thus, both the Russian and Belarusian Laws on environmental Protection contain principles that are directly or indirectly related to the goals of sustainable development. Some of them directly consolidate the provisions of SDG 11 in terms of achieving target 11.4.

\section{CONCLUSION}

Since the Federal Law "On Objects of Cultural Heritage (historical and Cultural monuments) of the peoples of the Russian Federation" does not contain an article containing the principles of legal regulation of public relations that constitute the subject of legal regulation of this law, it is necessary to supplement it with an article containing a list of such principles.

According to the Code of Culture of the Republic of Belarus, but taking into account the realities of the Russian Federation, it is proposed to include the principle of "preservation, conservation, careful use of cultural heritage objects"among these principles.

The introduction of these amendments and additions will make it possible to fix task 11.4. SDG 11 in the Federal Law "On Cultural Heritage Objects (Historical and Cultural Monuments) of the Peoples of the Russian Federation", and subsequently in the legislation of all subjects of the Russian Federation. This, in turn, will contribute to the further practical implementation of the Sustainable Development Goals in tourism and the protection of historical, cultural and natural heritage.

\section{AUTHORS' CONTRIBUTIONS}

There is no conflict of interests of the authors.

\section{REFERENCES}

[1] N. Vershitskaya, Public admistration innovations for sustainable developmentgoals, Sciences of Europe,72-2(72) (2021) pp. 16-17. DOI: https://doi.org/10.24412/3162-2364-2021-72-2-1617.

[2] D.E.Petrushenko, Resource saving as a factor of sustainable economic development, Scholarly notes PNU, 2(11) (2020)pp. 306-310.

[3] N.V. Agabekova, Generalized assessment of the achievement of sustainable development goals by 
the regions of the Republic of Belarus, Accounting and analysis,6(294) (2021) pp. 24-33.

[4] R.Timakova, V.Maksimeniuk, Sustainable tourism development at the level of health-improving tourism: social-legal aspect, E3S Web of Conferences,296(2021) $05018 . \quad$ DOI: https://doi.org/10.1051/e3sconf/202129605018.

[5] A.N. Borisov, Impact of the UN Millennium Development Goals on the development of Russian regions, Ethnic society and interethnic culture,4(154) (2021) pp.64-80.

[6] Voluntary National Review of the Implementation of the 2030 Agenda for Sustainable Development [Electronic resource]: Website of the Ministry of Economic Development of the Russian Federation.DOI:

http://www.economy.gov.ru/material/news/opublik ovan_pervyy_dobrovolnyy_nacionalnyy_obzor_dos tizheniya_rossiey_celey_ustoychivogo_razvitiya_o on.html.

[7] O.A. Shilina, Resources for the development of cultural and educational tourism in the regions of Central Russia. Economics and Entrepreneurship, 9(122) (2020) pp. 414-418.

[8] Convention concerning the Protection of the World Cultural and Natural Heritage. Collection of international treaties of the USSR, Release XLIV. Moscow, International relations, 1990, pp. 496-506.

[9] Convention for the Protection of Cultural Property in the Event of Armed Conflict. United Nations Treaty Series, 3511 (1956) pp. 292-372.

[10] A.T. Belekova, The growing role and responsibility of UNESCO in the preservation of monuments of cultural and historical heritage. Bulletin of Kemerovo State University, Series: Political, sociological and economic sciences, 6(1((19)) (2021) pp. 1-9.

[11] A.A. Edelkina, A.V. Larina, Mapping of UNESCO World Heritage Sites, Modern problems of territorial development, 1 (2020) pp. 4.

[12] A. Agapiou, UNESCO World Heritage properties in changing and dynamic environments: change detection methods using optical and radar satellite data. Heritage science, 9 (1) (2021) p. 64. DOI: https://doi.org/10.1186/s40494-021-00542-z.

[13] V.V. Maksimeniuk. Types of tourism depending on the purpose of travel: legal aspect, Vestn. Polots. state un-that, Series D, Econ. and jurid. Science, 14 (2018) pp. 200-208.
[14] A. Zh.Tulepbergenova, Approaches to the definition of cultural tourism, Current research, 24(27) (2020)pp. 71-73. DOI: https://apni.ru/article/1685-podkhodi-kopredeleniyu-kulturno-poznavateln.

[15] A.Yu. Savichev, On the issue of legislative consolidation of the classification of types of tourism, Law and policy, 4 (2021) pp. 63-71. DOI: https://doi.org/10.7256/2454-0706.2021.4.35527. https://nbpublish.com/library_read_article.php? $\mathrm{id}=35527$. 